\title{
G(i) Alpha
}

National Cancer Institute

\section{Source}

National Cancer Institute. G(i) Alpha. NCI Thesaurus. Code C19275.

Human G(i) Alpha Proteins (G-Alpha 1 Family) are 40-kDa guanine nucleotide-binding alpha protein subunits of heterotrimeric G protein transducers (alpha, beta, gamma) in transmembrane signaling systems involved in hormonal regulation of adenylate cyclase. Containing virtually identical/similar beta and gamma chains, G proteins are most disting uished by alpha chains. G(i) proteins (alpha(i) subunit) inhibit cyclase in response to beta-adrenergic stimuli. Specific alpha chain regions appear to interact with guanine nucleotides, receptors, effector enzymes, and G protein beta-gamma complex. G proteins that inhibit adenylate kinase and regulate other plasma membrane enzymes are substrates for pertussis toxin. $(\mathrm{NCl})$ 